\title{
Peningkatan Keterampilan Menulis Recount Text Melalui Pendekatan Genre Based
}

\author{
${ }^{1}$ L. M. Melalolin, ${ }^{2}$ N. M. S. A. Hartini, ${ }^{3}$ N. W. S. Mahayanti \\ Jurusan Pendidikan Bahasa Inggris, Singaraja, Indonesia \\ Universitas Pendidikan Ganesha, Singaraja, Indonesia \\ e-mail: lenmelalolin@gmail.com¹, sriayu_h@yahoo.com, surya.mahayanti@undiksha.ac.id
}

\begin{abstract}
Abstrak
Penelitian ini bertujuan untuk mendeskripsikan peningkatan keterampilan menulis recount text setelah diterapkan pendekatan pembelajaran genre based approach pada siswa kelas VIII-A7 SMP Negeri 1 Singaraja tahun ajaran 2018/2019. Jenis penelitian yang digunakan dalam penelitian ini adalah penilitian tindakan kelas yang dilaksanakan dalam 2 siklus. Subjek penelitian adalah siswa SMP Negeri 1 Singaraja kelas VIII-A7 yang berjumlah 32 orang, terdiri dari 17 orang laki-laki dan 15 orang perempuan. Teknik pengumpulan data yang digunakan dalam penelitian ini diperoleh dari data proses pembelajaran yang meliputi lembar observasi dan angket serta data hasil belajar yang diperoleh dari hasil penulisan siswa tentang recount text. Data hasil penelitian dianalisis menggunakan cara kuantitatif dan deskriptif kualitatif. Hasil analisis data menunjukkan bahwa terjadi peningkatan keterampilan menulis setelah adanya penerapan pendekatan genre based, hal ini dapat dilihat dari hasil yang dicapai pada masing-masing siklus dimana jumlah siswa yang mencapai KKM meningkat jika dibandingkan dengan hasil pre-test. Jumlah siswa yang mencapai KKM pada pre-test sebanyak 7 orang atau $21.87 \%$, selanjutnya peningkatan yang cukup signifikan terjadi pada siklus I yaitu sebanyak 21 orang atau $65.63 \%$ dan terus mengalami peningkatan pada siklus II sebanyak 25 orang tau $78.13 \%$. Dengan demikian terjadi peningkatan angka rata-rata persentase dari pre-test ke siklus I sebanyak $56.26 \%$, sedangkan dari siklus I ke siklus II sebesar 12.5\%. Akhirnya dapat disimpulkan bahwa genre based approach dapat meningkatkan keterampilan menulis recount text pada siswa kelas VIII-A7 SMP Negeri 1 Singaraja tahun ajaran 2018/2019.
\end{abstract}

Kata kunci: keterampilan menulis, recount text, genre based approach

\begin{abstract}
This research aims to determine the improvement in writing skill of recount text after applying the genre based approach to the students of VIII-A7 SMP Negeri 1 Singaraja in 2018/2019 Academic Year. The kind of research that used in this research was classroom action research which is carried out in two cycles. The subject of this study were the students of VIII-A7, SMP Negeri 1 Singaraja which consisted of 32 students, they were 17 boys and 15 girls. Data collection techniques used in this study obtained from the teaching process that included observation sheets and the result of students' writing about recount text. The results of the research analyzed by using quantitative and qualitative descriptive. The data analysis in this study indicate that there is an improvement of writing skill after applying the genre based approach, it can be seen from the students' result of each cycle where the number of students who achieved the criteria of success are improved in comparing with the result of pre-test. There were 7 or $21.87 \%$ students who achieved the criteria of success in pre-test, 21 or $65.63 \%$ students for the first cycle, and 25 or $78.13 \%$ students achieved the criteria of success in second cycle. Thus, it can be concluded that the applying of genre based approach can improve the writing skill in recount text of students in VIII-A7, SMP Negeri 1 Singaraja for Academic Year 2018/2019.
\end{abstract}

Keywords : writing skill, recount text, genre based approach

\section{Pendahuluan}

Dalam kurikulum 2013 pada Sekolah Menengah Pertama, pembelajaran Bahasa Inggris menggunakan pendekatan berbasis teks yang diaplikasikan melalui kegiatan pembelajaran guna mendorong peserta didik untuk mengembangkan pengetahuan dan keterampilan mereka dalam memahami dan menyusun berbagai jenis teks sesuai dengan jenjang pendidikan dimana mereka berada. Keterampilan berbahasa mempunyai empat komponen, yaitu keterampilan mendengar, berbicara, membaca dan menulis. Dari keempat keterampilan 
yang ada, menulis merupakan salah satu keterampilan penting yang perlu dikuasai oleh pemakai bahasa. Aktifitas menulis merupakan elemen pendidikan sekolah yang paling berharga, namun kenyataan yang terjadi keterampilan ini kurang mendapat perhatian. Jarang sekali guru memiliki peluang untuk mempertimbangkan potensi atau kemampuan menulis. Kemampuan atau keterampilan menulis tidak datang begitu saja melainkan harus dipelajari terlebih dahulu.

Suparno (2008) mengungkapkan pendapatnya mengenai menulis yaitu: meletakkan simbol grafis yang mewakili bahasa yang dimengerti oleh orang lain. Dengan demikian dapat disimpulkan bahwa menulis merupakan kegiatan berupa penuangan ide atau gagasan melalui aktivitas yang aktif dan produktif dalam bentuk simbol grafis baik huruf maupun angka secara sistematis sehingga dapat dipahami oleh orang lain. Keterampilan menulis memiliki beberapa manfaat seperti yang dikemukakan oleh Komaidi (2008) antara lain: menimbulkan rasa ingin tahu (curiosity) dan melatih kepekaan dalam melihat realitas di sekitar. Selain itu, kegiatan menulis akan menambah wawasan dan pengetahuan tentang apa yang ditulis dan membuat seseorang terlatih untuk menyusun pemikiran dan argumen secara runtut, sistematis, dan logis. Dari pendapat tersebut dapat disimpulkan bahwa melalui kegiatan menulis seseorang dapat mengetahui kemampuan dirinya dalam berargumen atau mengorganisasikan ide dan gagasan secara baik dan sistematis, tetapi juga menumbuhkan rasa ingin tahu yang tinggi terhadap sesuatu yang baru yang secara otomatis dapat memperkaya wawasan dan pengetahuan tentang apa yang ditulis. Bahkan dengan menulis seseorang dapat menggunakan bahasa secara tertib dan teratur.

Terlepas dari peran krusial menulis terhadap perkembangan intelektual, ternyata masih terdapat berbagai masalah yang terjadi. Seperti hasil penelitian yang dilakukan oleh Allington (2011) menegaskan bahwa masalah terbesar yang menyebabkan siswa mengalami kesulitan dalam menulis ialah karena kurangnya waktu yang diatur untuk melatih kemampuan menulis, sehingga berdampak pada penguasaan kosakata dan minimnya pemahaman tentang teknik menulis. Seperti ketika siswa diminta untuk menunjukkan kemampuan menulis, mereka terlihat kesulitan dalam memberikan detail dan argumen untuk mendukung gagasan utama yang mereka tulis.

Beberapa jenis teks yang digunakan sebagai bahan ajar untuk keterampilan menulis pada jenjang SMP antara lain descriptive, report, narrative, recount, dan masih banyak lagi. Yang menjadi fokus penelitian ini ialah teks Bahasa Inggris berbentuk recount (recount text). Recount text merupakan jenis teks yang mempunyai kaitan erat dengan kehidupan sehari hari dari penulisnya. Menurut Pardiyono (2007) recount text adalah jenis teks yang menceritakan kepada pembaca tentang sesuatu yang pernah terjadi atau menceritakan kembali peristiwa masa lampau. Di sisi lain Anderson \& Anderson (2002) memberikan pendapatnya tentang teks recount yaitu sebuah teks yang menceritakan sejumlah kejadian di masa lampau dalam sebuah rangkaian waktu tertentu secara berurutan. Dengan demikian dapat dismipulkan bahwa recount text adalah jenis teks yang berfungsi untuk menceritakan kembali tentang peristiwa - peristiwa yang telah terjadi dalam kurun waktu tertentu dan biasanya kejadian - kejadian tersebut ditulis dalam sebuah urutan waktu yang terstruktur. Teks ini dimulai dengan menceritakan tokoh dalam cerita, bagaimana peristiwa tersebut dimulai, dimana dan kapan peristiwa tersebut terjadi. Teks recount ditulis dengan tujuan untuk memberikan informasi, menghibur pembacanya atau bisa juga keduanya yaitu memberikan informasi sekaligus menghibur pembacanya. Derewianka (2003) mengemukakan pendapatnya tentang tujuan dari teks recount yaitu mendata dan mendeskripsikan pengalaman - pengalaman masa lampau dengan cara menceritakan kembali peristiwa peristiwa tersebut dalam sebuah urutan yang sistematis.

Dengan melihat pentingnya keterampilan menulis serta pembelajaran teks recount yang perlu diajarkan kepada siswa di jenjang SMP, maka dalam kurikulum 2013 keterampilan menulis teks recount berperan penting sebagai bagian yang perlu diterapkan. Meskipun demikian, tidak dapat dipungkiri bahwa masih terdapat beberapa masalah yang dialami siswa dalam meningkatkan keterampilan menulis teks recount saat pembelajaran Bahasa Inggris. Hal ini tergambar lewat observasi awal yang dilakukan oleh penulis pada pembelajaran Bahasa Inggris di Kelas VIII A7 SMP Negeri 1 Singaraja. 
Berdasarkan hasil observasi, ditemukan beberapa masalah dalam pembelajaran di kelas antara lain : guru masih menggunakan pendekatan atau strategi pembelajaran yang konvensional saat mengajarkan materi recount text. Siswa hanya diberi tugas secara langsung untuk menulis pengalaman mereka dalam bentuk teks tanpa ada latihan - latihan terbimbing yang mengarahkan mereka untuk mengenal elemen - elemen yang terdapat dalam teks tersebut terlebih dahulu. Hal ini membuat siswa menjadi kurang tertarik untuk meningkatkan keterampilan mereka dalam menulis. Selanjutnya, siswa terlihat masih sangat sulit untuk mengembangkan penulisan mereka karena kurangnya latihan atau stimulus yang membimbing mereka baik secara berkelompok maupun individu. Ini merupakan akibat dari lemahnya metode atau strategi pembelajaran yang digunakan oleh guru. Selain itu, kurangnya penguasaan simple past tense juga menjadi salah satu faktor yang menyebabkan siswa mengalami kesulitan dalam menulis, karena mereka takut membuat kesalahan. Semua gejala tersebut membuat siswa menjadi tidak termotivasi dan kurang aktif dalam pembelajaran. Masalah - masalah tersebut di atas berdampak pada prestasi belajar dan juga partisipasi siswa dalam pembelajaran khususnya pada materi recount text. Dimana hasil belajar mereka menunjukkan hanya $21,87 \%$ dari total keseluruhan siswa di kelas atau sekitar 7 dari 32 siswa yang memenuhi KKM atau mencapai nilai minimal 78 , sedangkan sisanya sebanyak $78.12 \%$ atau sekitar 25 dari 32 siswa tidak mencapai KKM dengan nilai antara 40 - 73.

Memperhatikan permasalahan yang telah diuraikan sebelumnya, serta pentingnya keterampilan menulis dalam Bahasa Inggris khususnya teks recount, maka upaya untuk meningkatkan keterampilan siswa adalah hal yang sangat penting untuk dilakukan. Dari beberapa sumber bacaan yang penulis temui ada beberapa pendekatan, strategi maupun metode pembelajaran yang dapat membantu siswa dalam meningkatkan keterampilan menulis teks recount. Namun, setelah mempertimbangkan masalah riil yang dialami oleh siswa Kelas VIII A7, maka pendekatan atau model pembelajaran yang dipilih harus memiliki beberapa kriteria yang cocok untuk mengatasi kesulitan yang dialami siswa, antara lain: siswa diarahkan atau dibimbing untuk bisa meningkatkan keterampilan menulis teks recount secara terarah mulai dari penanaman konsep, pemberian contoh teks yang relevan kemudian siswa melatih kemampuan mereka dalam menulis secara terbimbing di dalam kelompok hingga mereka secara mandiri dapat menuliskan pengalaman pribadi masing - masing dalam bentuk recount text. Setiap siswa diberikan kesempatan untuk memahami lebih banyak tentang penggunaan simple past tense, terlebih khusus menguasai kata kerja past participle dengan baik. Sehingga membuat mereka lebih gampang untuk mengorganisasikan ide mereka ke dalam sebuah teks recount yang benar. Siswa akan lebih termotivasi untuk belajar melalui serangkaian aktivitas yang diberikan dalam sebuah pendekatan atau model pembelajaran yang berbeda dari biasanya. Salah satu pendekatan atau model pembelajaran yang cocok dengan kriteria tersebut adalah Genre Based Approach.

Genre Based Approach merupakan pembelajaran yang berorientasi pada kemampuan siswa untuk menyusun teks. Metode pembelajaran ini berdasar pada pemodelan teks dan analisis terhadap fitur-fiturnya secara eksplisit serta fokus pada hubungan antara teks dan konteks penggunaannya. Derewianka (2003) berpendapat bahwa pendekatan ini bertujuan untuk membantu siswa menjadi peserta yang efektif dalam lingkungan akademik dan profesionalnya, serta dalam komunitas yang lebih luas. Dalam Pembelajaran Berbasis Teks guru mengenalkan teks dan tujuannya, serta fitur-fiturnya, dan membimbing siswa memproduksi teks melalui proses pemberian bantuan (scaffolding). Pembelajaran Berbasis Teks melibatkan proses di mana guru membantu siswa dalam memproduksi teks dan secara bertahap mengurangi bantuan tersebut sampai siswa mampu menproduksi teks sendiri. Richards (2015) mengatakan pembelajaran diorganisasikan ini dilakukan dengan menggunakan berbagai macam teks yang terkait dengan kebutuhan siswa, dan siswa diberikan latihan dalam berbagai macam teks sampai mereka mampu memproduksi teks tanpa bantuan dan bimbingan guru.

Dari penjelasan tersebut, dapat disimpulkan bahwa Genre Based Approach adalah pembelajaran yang mampu membuat siswa memahami dengan benar teks yang mereka pelajari baik dari sisi pengetahuan maupun keterampilan. Hal ini terjadi karena pendekatan yang digunakan disesuaikan dengan kebutuhan serta tingkat pemahaman siswa di dalam 
lingkungan belajarnya. Pembelajaran berbasis teks untuk pembelajaran menulis adalah sebuah kolaborasi antara proses dan hasil belajar. Bagaikan dua sisi mata uang yang berbeda namun mempunyai satu kesatuan yang tidak dapat dipisahkan, demikian pula dengan Genre Based Approach yang mana digunakan sebagai sebuah pendekatan atau strategi pembelajaran yang bermakna untuk mengajarkan keterampilan menulis sekaligus juga dapat menghasilkan sebuah produk tulisan yang baik sesuai konteks pembelajaran teks yang diajarkan. Sebagai sebuah pendekatan, Genre Based Approach merujuk pada proses penulisan yang ditunjukan secara sistematis dan jelas yang dapat diikuti oleh guru maupun siswa. Hal ini mengindikasikan bahwa Genre Based Approach dapat diterapkan untuk mengajarkan keterampilan menulis (writing skill).

Beberapa penelitian telah dilakukan sebelumnya terkait dengan penerapan Genre Based Approach untuk meningkatkan keterampilan menulis, diantaranya Sulastri (2010), Anggaira (2012), Indrayanti (2013), Kusumaningtyas (2014), dan Ningsih (2015). Keseluruhan penelitian yang dilakukan oleh para peneliti sebelumnya ini menunjukan hasil yang sama, yaitu peningkatan yang signifikan terhadap keterampilan siswa dalam menulis setelah diterapkannya Genre Based Approach. Memperhatikan masalah yang ada dan kesesuaian kriteria yang dipilih (Genre Based Approach), serta berkaca dari keberhasilan penelitianpenelitian terdahulu maka peneliti merasa terinspirasi untuk melakukan penelitian ini dengan tujuan untuk menerapkan Genre Based Approach untuk meningkatkan keterampilan siswa dalam menulis teks recount di SMP Negeri 1 Singaraja. Dengan melakukan penelitian ini diharapkan pemahaman serta keterampilan siswa-siswi dalam menulis teks recount akan meningkat dan pembelajaran semakin bermakna dan menyenangkan.

\section{Metode}

Penelitian ini dilakukan pada kelas VIII-A7 dengan jumlah siswa 32 orang, terdiri dari 17 orang laki-laki dan 15 orang perempuan. Jenis penelitian yang digunakan adalah Penelitian Tindakan Kelas (PTK). Penelitian tindakan kelas dikenal dengan karakteristik adanya jalan keluar yang ditempuh sebagai pemecahan masalah yang ditemukan oleh guru dalam proses pembelajaran di kelas. Seperti yang dikatakan oleh King (2013), penlitian tindakan kelas merupakan bentuk investigasi yang didesain oleh guru untuk mengatasi masalah serta meningkatkan profesionalisme tenaga pendidik di dalam kelas.

Prosedur yang digunakan dalam penelitian ini diadaptasi dari Kemmis dan Taggart (2002) yang mempunyai empat tahapan, antara lain : planning (perencanaan), action (tindakan), observation (pengamatan), dan reflection (refleksi) dan diterapkan dalam dua siklus.



Gambar 1. Prosedur Penelitian diadaptasi dari Kemmis dan Taggart (2002)

Untuk mengumpulkan data, penulis menggunakan data proses pembelajaran dan data hasil belajar siswa. Instrumen pengumpulan data yang digunakan dalam penelitian ini ialah 
lembar observasi, angket dan test. Lembar observasi bertujuan untuk melihat kesesuaian antara urutan pelaksanaan pembelajaran dengan skenario yang telah dirancang sebelumnya. Angket bertujuan untuk mengetahui respon siswa terhadap penerapan genre based approach. Test digunakan untuk melihat peningkatan keterampilan menulis siswa tentang recount text. Data yang diperoleh dianalisis dengan cara kuantitatif dan deskriptif kualitatif.

\section{Hasil dan Pembahasan}

Sebelumnya bahwa penelitian ini dilakukan dalam 2 siklus. Tahap pelaksanaan pada masing-masing siklus dilakukan dalam 4 pertemuan. Pada siklus I data dikumpulkan dengan menggunakan lembar observasi yang mana diamati pada setiap pertemuan dan post-test yang diberikan pada pertemuan terakhir. Hasil post-test pada siklus I menunjukan 21 siswa atau sekitar $65.63 \%$ telah mencapai KKM. Hal ini menggambarkan sebuah peningkatan yang cukup baik jika dibandingkan dengan hasil pre-test dimana hanya 7 orang atau sekitar $21.87 \%$ yang mencapai KKM.

Penelitian pun dilanjutkan pada siklus II yang bertujuan untuk mengkonfirmasi hasil siklus I. Sama halnya dengan siklus I, tahap pelaksanaan pada siklus II dilakukan dalam 4 pertemuan. Data yang dikumpulkan pada siklus ini menggunakan lembar observasi pada setiap pertemuan, kemudian post-test dan angket yang diberikan pada pertemuan terakhir. Hasil post-test pada siklus II tetap menunjukan peningkatan dimana jumlah siswa yang mencapai KKM bertambah dari 21 orang atau $65.63 \%$ pada siklus I menjadi 25 orang atau sekitar $78.13 \%$. Peningkatan keterampilan siswa yang diukur dengan menggunakan instrumen tes dapat dilihat pada gambar 1.

Melalui penelitian tindakan kelas yang telah dilakukan ini, peneliti menyadari bahwa keberhasilan dalam meningkatan keterampilan siswa untuk menulis recount text dapat terjadi melalui Genre Based Approach jika diterapkan secara efektif. Hasil pengumpulan data menunjukan bahwa pada Siklus II keterampilan siswa dalam menulis recount text berhasil ditingkatkan secara baik serta mampu menjawab rumusan masalah yang ada. Hal ini membuktikan teori atau pendapat yang dikatakan oleh Dirgeyasa (2016) bahwa Genre Based Approach merupakan salah satu pendekatan terbaru, praktis serta efektif untuk pembelajaran writing dimana pendekatan ini relevan dengan siswa yang mempunyai kompetensi dan motivasi belajar yang rendah.

Model pembelajaran ini sangat berguna untuk menuntun siswa dalam hal menulis mulai dari hal yang paling sederhana sampai kepada sesuatu yang kompleks. Dari karakteristik peningkatannya, akan sangat terlihat dimana siswa yang awalnya sangat bergantung kepada bantuan teman atau guru perlahan-lahan akan menjadi siswa yang mandiri atau mampu memproduksi sebuah penulisan dengan kemampuannya sendiri berdasarkan tahapantahapan yang telah dipelajari dalam Genre Based Approach.

Sebelum penelitian tentang Genre Based Approach ini diterapkan, sebagian besar peserta didik mengalami masalah dalam menulis recount text. Masalah yang muncul pun beragam, dimulai dari penggunaan pendekatan atau strategi pembelajaran oleh guru yang masih konvensional saat mengajarkan materi recount text. Selanjutnya, siswa terlihat masih sangat sulit untuk mengembangkan penulisan mereka karena kurangnya latihan atau stimulus yang membimbing mereka baik secara berkelompok maupun individu. Serta, kurangnya penguasaan simple past tense menjadi salah satu faktor yang menyebabkan siswa mengalami kesulitan dalam menulis, karena mereka takut membuat kesalahan.

Akhirnya masalah-masalah tersebut perlahan-lahan dapat diatasi lewat penerapan Genre Based Approach. Sebagian besar siswa merasa terbantu dalam memahami serta meningkatkan keterampilan mereka untuk menulis recount text. Pendekatan ini memberikan banyak kesempatan bagi siswa untuk berlatih dan mengenal lebih jauh tentang recount text melalui serangkaian aktifitas yang diberikan sejak awal pengenalan teks hingga pada tahap akhir siswa mampu menghasilkan sebuah recount text secara mandiri.

Hasil penelitian pada Siklus I telah menunjukan hasil yang baik sesuai dengan apa yang diharapkan, namun karena masih ada beberapa siswa yang belum menunjukkan peningkatan yang cukup baik maka peneliti memutuskan untuk melanjutkan penelitian dengan melakukan 
satu siklus tambahan. Sebagai hasilnya, penulisan recount text yang dicapai pada Siklus II ini menunjukan perkembangan yang sangat baik, dimana jumlah siswa yang tidak mencapai KKM menjadi berkurang dengan menunjukan progres yang cukup meningkat.

Di sisi lain, penerapan Genre Based Approach dalam menulis recount text mendapat respon yang berbeda dari masing - masing siswa. Untuk mengetahui interaksi serta respon yang ditunjukan siswa selama proses pembelajaran berlangsung maka peneliti menggunakan lembar observasi dan juga angket. Hasil dari lembar observasi menggambarkan jalannya tahapan pelaksanaan Genre Based Approach berdasarkan apa yang telah direncanakan oleh peneliti sebelum melakukan penelitian ini. Di saat yang bersamaan, partisipasi siswa dalam proses pembelajaran pun turut diamati. Partisipasi yang baik ditunjukkan oleh siswa selama proses pembelajaran dengan melaksanakan aktifitas atau tugas - tugas yang diberikan sesuai dengan instruksi yang tersedia, serta proses belajar yang menggunakan sistem student oriented membuat siswa menjadi lebih termotivasi untuk belajar. Pengumpulan data menggunakan angket juga menunjukan hasil yang memuaskan, dimana siswa merasa pemahaman dan keterampilan dalam menulis recount text mereka menjadi meningkat setelah berlatih dengan menggunakan serangkaian aktifitas yang dibuat dalam Genre Based Approach.

Jika dilihat dari peningkatan keterampilan menulis recount text yang dialami oleh siswa dalam penelitian ini, maka dapat disimpulkan bahwa hasilnya sejalan dengan beberapa penelitian terdahulu tentang Genre Based Approach yang dilakukan oleh Sulastri (2010), Anggaira (2012), Indrayanti (2013), Kusumaningtyas (2014), dan Ningsih (2015), dimana penelitian yang mereka lakukan berhasil meningkatkan kemampuan siswa dalam menulis beberapa jenis teks yang berbeda dalam Bahasa Inggris. Hal ini semakin menambah panjang daftar penelitian yang berhasil menggunakan Genre Based Approach sebagai sebuah model pembelajaran yang sangat bermanfaat dan memberikan makna bagi siswa dalam meningkatkan pemahaman tentang berbagai jenis teks berbahasa Inggris, sehingga pada akhirnya merekapun mampu menuangkan ide dan gagasan mereka dalam sebuah teks sesuai dengan kaidah dan struktur penulisan yang benar.

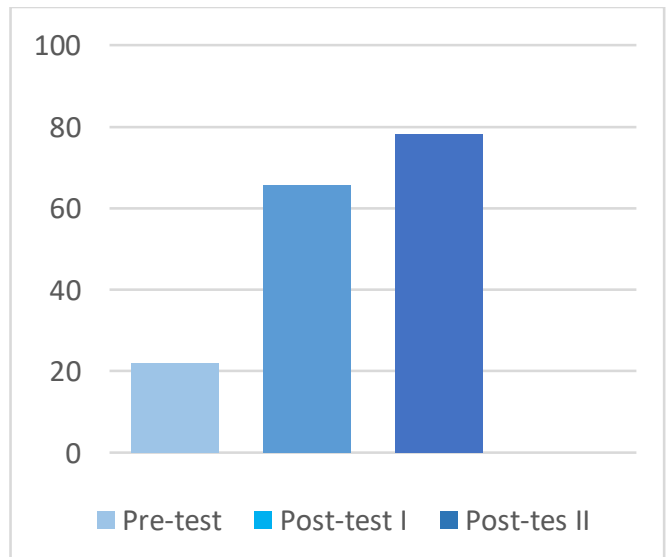

Gambar 2. Grafik nilai siswa pada pre-test, pos-test I dan pos-test II.

\section{Simpulan dan Saran}

Tujuan utama pelaksanaan penelitian tindakan kelas ini ialah bagaimana meningkatkan keterampilan menulis recount text melalui penerapan Genre Based Approach. Berangkat dari hasil penelitian yang telah dijelaskan pada bagian sebelumnya, dapat dilihat bahwa kemampuan siswa dalam menulis recount text telah berhasil ditingkatkan. Model pembelajaran Genre Based Approach terbukti mampu membantu siswa dalam mengatasi masalah - masalah yang ditemui dalam mempelajari recount text. Meningkatnya keterampilan siswa dapat dilihat dari berbagai data yang dikumpulkan, antara lain: hasil tes, lembar observasi dan juga hasil angket. Secara umum, dapat dikatakan bahwa keterampilan siswa 
dapat ditingkatkan melalui penerapan Genre Based Approach, siswa juga menunjukkan interaksi, partisipasi serta respon yang baik saat proses pembelajaran berlangsung.

Sangatlah bermakna dan bermanfaat bagi guru maupun siswa. Salah satu poin vital dari pembelajaran recount text ialah siswa mampu menciptakan sebuah penulisan yang menceritakan pengalaman mereka di masa lampau dengan memperhatikan struktur teks serta unsur kebahasaan yang tepat. Penelitian ini memberikan sebuah bukti nyata tentang efektifnya penggunaan Genre Based Approach untuk membantu siswa meningkatkan keterampilan menulis recount text. Melalui berbagai aktifitas yang terbimbing dan pendekatan dari yang paling umum ke bagian yang paling khusus dari recount text maka pada akhirnya siswa dapat menuangkan ide dan pengalaman mereka kedalam sebuah teks.

Terkadang siswa merasa bosan dengan model atau pendekatan pembelajaran yang umumnya digunakan oleh guru mata pelajaran di sekolah. Hal ini berdampak pada motivasi mereka untuk belajar, tetapi juga berpengaruh pada hasil belajar yang dicapai. Namun, saat Genre Based Approach diterapkan oleh peneliti, siswa justru merasa lebih mudah untuk memahami teks serta termotivasi untuk mencari tahu segala informasi yang berkaitan dengan teks yang dipelajari tersebut. Pendekatakan ini juga sesuai dengan tuntutan kurikulum yang digunakan di Indonesia saat ini yang mana mengharuskan guru untuk memberikan banyak kesempatan kepada siswa dalam bereksplorasi dan mengolah informasi menggunakan kemampuan mereka sendiri atau yang umumnya dikenal dengan sebutan student oriented.

Genre Based Approach sangat memungkinkan untuk digunakan secara berkelompok, berpasangan maupun secara individu, sehingga siswa dapat saling membantu jika ada masalah - masalah yang mereka temukan dalam proses pembelajaran. Banyak hal penting yang harus diperhatikan guru dalam membuat rancangan pembelajaran menggunakan Genre Based Approach sehingga pendekatan ini dapat berjalan secara efektif dan efisien, diantaranya tujuan, materi, media, latihan atau tugas - tugas serta keterlibatan siswa selama proses pembelajaran berlangsung.

Berdasarkan simpulan tersebut, dapat diajukan saran-saran sebagai berikut: 1). Bagi pihak sekolah agar dapat menerapkan genre based approach dalam pembelajaran teks Bahasa Inggris yang dapat menyenangkan dan bermakna di sekolah. 2). Bagi guru disarankan agar dapat menerapkan genre based approach dalam proses pembelajaran sehingga dapat menjadi motivasi untuk meningkatkan kualitaas pembelajaran yang lebih bermakna dan sesuai dengan tuntutan kurikulum yang mana mengharuskan proses pembelajaran lebih banyak berpusat pada siswa. 3). Bagi siswa kiranya dapat memanfaatkan genre based approach sebagai pendekatan pembelajaran yang menyenangkan guna meningkatkan hasil belajar khususnya keterampilan menulis recount text sesuai dengan struktur dan tata bahasa yang baik dan benar.

\section{Daftar Pustaka}

Allington, R. L. (2011). What really matters for struggling readers. New York: Addison Wesley Longman.

Anderson, M., and Anderson, K. (2002). Text Type in English 3. Australia: Macmillan.

Derewianka, B. (2003). 'Trends and Issues in Genre-based Approaches'. RELC Journal. 34.2. 133-54. London: Continuum.

Dirgeyasa, Wy. I. (2016). Genre-Based Approach: What and How to Teach and to Learn Writing. Canadian Center of Science and Education.

Kemmis, S., \& Taggart, M. (2002). R. 1988. The action research planner.

Klinton, K. (2013). Action Research Report: Note-taking Strategies.

Komaidi, D. (2007). Aku Bisa Menulis. Panduan Praktis Menulis Kreatif Lengkap. Yogyakarta: Sabda Media.

Pardiyono. (2007). Pasti Bisa: Teaching Genre Based Writing. Yogyakarta: Penrbit Andi. 
Richards, J.C. (2015). Key Issues in Language Teaching. Cambridge: Cambridge University Press

Rudi Hartono, S. S., \& Pd, M. (2005). Genre of texts. English Department Faculty of Language and Art. Semarang State University.

Suparno, M. Y. (2008). Keterampilan dasar menulis. Jakarta: Universitas Terbuka. 